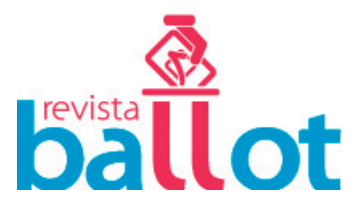

\title{
Two faces of internal life of political parties in Western Balkans
}

Gordana Siljanovska-Davkova ${ }^{1}$ (University Ss. Cyril and Methodius, Macedônia) goga@ukim.edu.mk

Skopje 1000,Macedonia (FYROM)

1. Professor of Constitutional Law and Political System, University of Ss" Cyril and Methodius", Faculty of Law “ Iustinianus Primus", Skopje, Republic of Macedonia 


\begin{abstract}
The enhancement of internal party democracy and development of democratic organizational structures of political parties are burning issues in the consolidating democracies of Western Balkans. The degree of internal party democracy depends on: vertical power sharing; the role and the status of the individual member; the role of the leader and party leadership; way of election of public functionaries; horizontal structures and the relation of the party to its supporters and civil society. I explore both the obvious and the hidden reasons and obstacles to the development of a democratic party life. Firstly, I shall analyse the legislation concerning party organisation and internal party democracy. Then, I'll try to differentiate the model of party organisation through its three faces: the party on the ground, the party in the central office and the party in public office2. At the end, I'll draw conclusions and recommendations for changes needed for internal party democratisation. Internal party democracy is like Janus with two faces: one that is authoritarian and oligarchic and another-poliarchic and democratic. The first dominates over the second one. Worse, the oligarchic tendencies within internal party life are regularly transferred to the institutions, infecting them with partitocrazia.
\end{abstract}

Keywords: party; internal party life; organisational party structures; oligarchic tendencies; party democracy; vertical power sharing; horizontal power sharing; partitocrazia; Western Balkans; Republic of Macedonia

\title{
As duas faces da vida interna dos partidos políticos dos Balcãs Ocidentais
}

\section{Resumo}

O aprimoramento da democracia interna partidária e o desenvolvimento de estruturas organizacionais democráticas dos partidos são tópicos de grande relevância nas democracias em consolidação dos Balcãs Ocidentais. O grau de democracia partidária interna depende dos seguintes fatores: compartilhamento de poder vertical; o papel e o status individual dos filiados; o papel do líder e da liderança partidária; a forma de eleição dos funcionários públicos; estruturas horizontais e a relação do partido com seus apoiadores e sociedade civil. Explorar-se-á tanto as razóes e obstáculos mais óbvios para o desenvolvimento de uma vida partidária democrática quanto aqueles mais velados. Primeiramente, será feita uma análise da legislação pertinente à organização partidária e democracia interna dos partidos. Depois, uma tentativa de diferenciar o modelo de organização partidária através de suas três facetas: a base do partido, a gestão interna do partido, o partido no exercício de cargos públicos ${ }^{2}$. Ao final, serão tomadas conclusões e dadas recomendações para mudanças necessárias à democratização interna dos partidos. A democracia partidária interna, assim como o deus romano Jano, possui duas faces: uma oligárquica e autoritária e outra poliárquica e democrática. A primeira predomina em relação à segunda. Pior, as tendências oligárquicas dentro da vida partidária interna são regularmente transferidas para instituições, infectando-as com partidocracia.

Palavras-chave: partido político; vida partidária interna; estruturas organizacionais partidárias; tendências oligárquicas; democracia partidária; compartilhamento de poder vertical; compartilhamento de poder horizontal; partidocracia; balcãs ocidentais; república da macedônia

2. More about this: R.S Katz, and P. Mair, The Ascendency of the Party in Public Office: Party Organizational Change in Twentieth-Century Democracies, in: J.R. Montero, J.J Linz (eds) Political Parties: Old Concepts and New Challenges, Oxford University Press, Oxford, (2002), pp 122-133 


\section{Introduction}

There is an enduring interest of comparative political science for political parties, dating back to Ostrogorski and Michels. As a basic link/agent between the citizens and their representatives they have had a vital role in liberal democracy and as such have been considered as a central object of the liberal theory. Starting from their emergence in the second half of the $19^{\text {th }}$ and in the beginning of the $20^{\text {th }}$ twentieth century until today, the political science is patiently following their evolution and covering their different dimensions, constituting them as one of the most important sub-fields.

Parties have passed a long journey. They were created as a as "cadre" or "mass" parties either internally (by existing elites which created electoral machinery in order to maintain the political power) or externally (through social mobilisation of underrepresented groups intending to seek for political power) ${ }^{3}$.

Michels pictured the party democratic deficits through his "iron law of oligarchy".

The Western Europe between two wars faced the deep crisis of social-democratic parties and the existence of ideological extremism, both on left and right. Post-war era, as cold-war period, promoted dichotomy: west democracy vs. east, democracy vs. totalitarism, as well as democratic vs. totalitarian parties. Post-war political approaches are characterized by dominance of social paradigm, and determination of political parties as social representation agents. Almond and Verba ${ }^{4}$, and Lipset and Rokkan in their cleavage concept ${ }^{5}$, promote this approach. Later, the empirical political science was pre-occupied with the issue of party modernisation. Kircheimer promoted the aspect of "catch-all party", ${ }^{6}$ and Epstein spoke on organisational adaptation development of parties by means of new communication technologies. ${ }^{7}$ Other political scientists were pre-occupied by the phenomenon of partisan de-alignment (Dalton, Beck, and Flanagan ${ }^{8}$; Crewe and Denver ${ }^{9}$.

We have to stress Panebianco's concept of the "electoral-professional party"10 in which he explains the tendency for professional party apparatus and emancipation of the party leadership from the grass roots. From 1990s, empirical political science tended to mirror the

3. M. Duverger, M, Political Parties: Their Organization and Activity in the Modern State, Methuen, London, (1954).

4. G A,Almond, and S Verba, The Civic Culture: Attitudes and Democracy in Five Nations. Princeton Press, Princeton: (1963).

5. S M Lipset, and S. Rokkan, (eds), Party Systems and Voter Alignments, Free Press, New York (1967a).

6. O Kircheimer, The Transformation of Western European Party Systems in J. La Palombara and M.Weiner (eds.), Political Parties and Political Development, Princeton University Press, Princeton, (1966)

7. L D. Epstein, Political Parties in Western Democracies. Praeger, New York, (1967)

8. RJ Dalton, S Flanagan, and P.Beck, (eds.), Electoral Change in Advanced Industrial Democracies, Princeton University Press, Princeton, (1984).

9. J Crew, J, and Denver, (eds) Electoral Change in Western Democracies: A Framework for Analysis, St Martin's Press, New York, (1985).

10. A Panebianco, Political Parties: Organization and Power, Cambridge University Press, Cambridge (1988) 
migration of parties towards the state. Katz and Mair ${ }^{11}$ characterized those parties as "cartel" parties which try to utilize state resources for own party needs.

Indeed, party literature has studied the role of political parties within the nation state, conceptualizing them as institutions/factors with key role in/of its democratic legitimisation. But, in 1980s and 1990s, we could speak about changes on the ground.

The empirical political science mostly pays attention to: parties' mobilisation linkage role and function ${ }^{12}$; parties' vote-seeking role, and parties' role in the political electoral market; recruitment of political elites and public office holders (Ostrogorski, ${ }^{13}$ Michels $^{14}$, Eldersefeld ${ }^{15}$, Katz and Mair ${ }^{16}$, Panebianco ${ }^{17}$ ); parties as value based political entities with value determined relations with their supporters and inter partes, as well as value marked parties' selection and marketing of policy preferences (Robertson ${ }^{18}$, Budge and Farlie ${ }^{19}$; office-seeking role of political parties and their institutional environment (state organs, legal framework, electoral system, and media (Rae ${ }^{20}$, Muller $^{21}$, Lijphart ${ }^{22}$, Tsebelis $\left.{ }^{23} 2002\right)$.

I'll try to analyse and evaluate the organisational structures and internal party democracy, with special attention to parties in Western Balkans, including the case study of the internal life of the main parties in the Republic of Macedonia. There is considerable literature on party organisation and different party types, but I would like to re-examine party organi-

11. RS Katz, / P. Mair, Changing Models of Party Organization and Party Democracy: the Emergence of the Cartel party, Party Politics (1) 1,(1995), pp 5-28

12. K Lawson, K, Political Parties and Linkage, in K. Lawson (ed.), Political Parties and Linkage: A Comparative Prespective, Yale University Press, London, (1980).

13. Ibid

14. Ibid

15. S J Eldersveld, Political Parties. A Behavioral Analysis, Rand McNally, Chicago, (1964)

16. P S Katz, and P Mair, Party Organizations: A Data Handbook on Party Organizations in Western Democracies, 1960-1990, Sege, London, (1992b);

P S, Katz, and P. Mair, The Evolution of Party Organization in Europe: The Three Faces of Party Organization, in W. Crotty (ed.), Political Parties in Changing Age, special issue of American Review of Politics, 14, (1993), pp 593-617

R S Katz, and P. Mair, (eds), How Parties Organize. Change and Adaptation in Party Organizations in Western Democracies, Sage, London (1994)

17. Ibid

18. Robertson, D, A Theory of Party Competition, John Wiley \& Sons, London, (1976)

19. J Budge, J, and D. Farlie, Explaining and Predicting Elections: Issue Effects and Party Strategies in TwentyThree Democracies, Allen\& Unwin, London, (1983).

20. DW, Rae, The Political Consequences of Electoral Laws, New Haven.Conn.: Yale University Press, New Haven.Conn, 2nd edn. (1971).

21. WC, Müller, The Relevance of the State for Party System Change, Journal of Theoretical Politics, 5 (1993), pp 419-454

22. A Lijphart, A, Patterns of Democracy: Government Forms and Performance in Thirty-six Countries, Yale University Press, New Haven, Conn. (1999).

23. G Tsebelis, Veto Players, Princeton University Press, Princeton, (2002)

batlot http://www.e-publicacoes.uerj.br/index.php/ballot 
sation per se, intending to explore its organisational complexity: different models of party organisation (elite or cadre party, the mass party, the catch-all party, and the cartel party) and different party faces: "on the ground", "in the central office" and "in public office". Indeed, I am aware that there are no pure models of parties and that there is a hybrid/mix model, in which various models co-exist. Development of party organisation in the $20^{\text {th }}$ century is analysed by Richard S. Katz and Peter Mair ${ }^{24}$. They evaluate the changes of balance among three organisational faces of parties and the connection and impact of intra-party relations to popular trust or mistrust in politics and parties, support or alienation from politics and parties. Contemporary politics shows that there is a "free space/area" of anti-politics and anti-party parties which promote radicalism, xenophobia, racism, and anti-democratic sentiments". ${ }^{25}$

Marginalised, neglected and even forgotten citizens in the environment in which parties do not address citizen's interests but own interests, problematize the legitimacy of representative democracy. If the representative democracy is in crisis, then the parties as its main bridge between the citizens and politicians are also in deep crisis. Thus, the enhancement of internal party democracy and democratically functioning party organisational structures are burning issues, particularly within the consolidating democracies of Central and East Europe, Western Balkans and the Republic of Macedonia.

\section{General (Un)democratic picture of Western Balkans ${ }^{26}$}

Western Balkans is treated as a new geo-political region comprising the Former Yugoslav republics (Croatia, Serbia, Montenegro, Bosnia and Herzegovina and Macedonia) minus Slovenia plus Albania. ${ }^{27}$ It is often treated as an "Achiless' heel" 28 of Europe or even as "a hopeless case, doomed to a perpetual cycle of war and underdevelopment" ${ }^{\prime 2}$. From my angle of observation, the most vulnerable points are: partitocrazia, clientelism, corruption, and organized crime. As a contagious disease they penetrate every facet of life. We must not neglect

24. See R S Katz, and P. Mair, The Ascendency of the Party in Public Office: Party Organizational Change in Twentieth-Century Democracies, in: R. Gunter, J. R,Montero, J. Linz, (eds) Political Parties: Old Concepts and New Challenges, Oxford University Press, Oxford (2002) pp 113-135;

RS Katz, and P. Mair, The Evolution of Party Organization in Europe: The Three Faces of Party Organization, in W. Crotty (ed.), Political Parties in Changing Age, special issue of American Review of Politics, 14, (1993), pp 593-617

RS. Katz, P. Mair, Changing Models of Party Organization and Party Democracy: the Emergence of the Cartel party, Party Politics 1, (1995), pp 5-28

25. C.Mudde, The Paradox of the Anti-Party Party: Insights from the Extreme Right. Party Politics, 2. (1996) pp 265-276.

26. I have serious doubts about "Western Balkans" as a term from semantic point of view, but it is officially used by EU and its officials. Its problematic meaning became even more problematic after Croatian membership in EU in 2013. Its meaning is predominantly political, rather than geographical, covering the states of the South East Europe which are not members of EU, but are surrounded by EU members.

27. A Alibali, Balkani Prerëndimorapo Europa Adriatike. Korrieri, Tirana (21 August 2003)

28. A Moravcsik, The Choice for Europe: Social purpuse and state power from Messina to Maastricht, UCL Press London, (1999), pp 1

29. M Glenny M, and G. Knaus, Thessalonica and Beyond: Europe's Challenge in the Western Balkans, in European Stability Initiative, New York Free Press (2003) 
the ability of corruption to self-generate ${ }^{30}$ and its relation to organised crime. Despite the limited state funds for financing political parties, the electoral campaigns of the ruling parties have been increasingly more expensive. A weak judicial system lacking independence makes the fight against corruption difficult. According to Transparency International Corruptions Perceptions Index, Western Balkans countries are highly corrupted. Organised crime is a dreadful problem in Western Balkans, which is exported to EU. Human trafficking remains a question of deep concern. These are also transit countries for illicit drugs, smuggling of consumer products, and money laundering. In many areas the police, the customs officials, individuals in top state offices and politicians are involved in organised crime activities.

There is a need to strengthen the law enforcement institutions, but also to break ties between crime and politics in order to combat organised crime.

European integration is a process of immense historical importance for the Western Balkans, bringing re-unification of the artificially divided continent and giving Western Balkans a chance to catch up with Europe, to return to Europe and Western Civilisation,to identify with liberal democracy, to enable free movement and work of people wherever they wish in the EU. Without Western Balkans, EU is "an unfinished symphony" ${ }^{\text {"1 }}$. The enlargement will have a profound impact on Western Balkans democratic consolidation.

The aspirations of the Western Balkans peoples to reintegrate into mainstream and the "bottom up" pressure may be used to promote wider and deeper reforms. The results of the polls conducted all these years show very high percent of citizens were in favour of joining EU. But, the politicians in the Balkans often send overly optimistic messages in order to stay in power. We have to be realistically informed about the long and hard process of integration, as well as about its implications.

\section{Political Parties in Western Balkans}

There is a shortage of information and research on political parties in Western Balkans' countries. There are thorough studies on political parties in Central and Eastern Europe that have been published in post-communist era, several in South Eastern Europe, ${ }^{32}$ but yet there is a deficit of analyses on parties, party systems, parties' ideologies and parties' internal life in Western Balkans. ${ }^{33}$ Indeed, there is a need for co-operation and exchange of views and experience between political scientists and politicians as well as feedback of researches into the political parties themselves. Furthermore, having some specific regional political phenomena we need comparative studies. It is interesting to stress that political elites in Western Balkans are very interested to have good relations with the politicians from Western Europe, while

30. J Newell, Parties and Democracy in Italy, chp.1, 3, 9. Ashgate, Aldershot (2000), pp 53

31. G Ash, EU Enlargement: Unfinished Symphony, SEESP Newsletter No. 2, (July 2004)

32. I would like to mention some of them: Study on Political Parties and the Consolidation of Democracy in South Eastern Europe, (ed) G. Karasimeonov, Gorex Press, Sofia (2004); Organizational Structures and Internal Party Democracy in South Eastern Europe, (ed) G. Karasimeonov, Sofia (2005).

33. V. Goati, Political Parties and Parties' Systems, FPN, Podgorica, 2008; Political Parties and Voters in the States of Former Yugoslavia, (ed) Z. Lutovac, Beograd (2006); G. Siljanovska-Davkova, "Political Parties, Values and Democratic Consolidation" in Civic and Uncivic Values in Macedonia", (ed) S. Ramet, S, O. Listhung, and A. Shimkus, Palgrave Macmillan, London, (2013) 
underestimating and neglecting the regional contacts and cooperation. The prospects of EU membership for the Western Balkans countries will force a change in these attitudes. There is a need for new, post-modern regional approach to cooperation, as well a need to establishing a regional network of experts and politicians in this field.

As a participant in the project "Organisational structures and internal party democracy in South Eastern Europe" and Political Parties and voters in Former Yugoslav republics, I became aware that the political environment in all of them has some common characteristics such as: negative image of political elite in general and the political parties in particular; highly polarised and confronted climate between the main political parties; disputed elections; growing gap between the people (us) and politicians (them); loud call for more important role of civil society in decision making; need for more transparent, and efficient political parties which would serve the public interest. But, once again, it has been reaffirmed and confirmed that political parties remain sustainable and the most important actor and factor of democracy. Internal Party democracy has not been particularly developed in the parties in newly post-communist countries, thinks Biezen ${ }^{34}$. The internal party organisation was and is created in "top-down" manner.

\section{Internal Party Democracy in Western Balkans Countries}

Internal party democracy seems to be one of the most common challenges and crucial tasks the parties in Western Balkans face in the near future. This challenge is not the same in every country, and not even among political parties within each of them. Different aspects of internal party democracy are important for different countries and political parties, while some elements remain as common ones.

The legislation of the countries in Western Balkans pays particular attention to political parties. In all of them, the freedom to create political parties is guaranteed by the Constitution. The way political parties are created and function is regulated through a Constitution and/ or a law. In this sense, the main legal provisions on organisational matters and activities of political parties in Croatia are "materia constitutionis", and "materia legis. ${ }^{35}$ Citizens are free to establish political parties as long as they do not expound racial, religious or ethnic hatred, or use violence to seize power or influence state policy. There is no precise legislation concerning party organisation and internal party democracy in Bosnia and Hercegovina. ${ }^{36}$ The Constitution $^{37}$ or the law ${ }^{38}$ stipulates that parties are territorially organized. In my opinion, the legal

34. I. Biezen 2003. Political Parties in the New Democracies: Party Organization in Southern and East-Central Europe, Palgrave Macmillan, London (2003), pp 213

35. G Čular writes on this in "Organizational Development of Political Parties and Internal Party Democracy in Croatia" in (ed) Karasimeonov, G, Organizational Structures and Internal Party Democracy in South Eastern Europe, Gorex Press, Sofia, (2005), pp. 63-66

36. D Vuletic explains that the laws on political parties deal with obligatory issues concerning registration and they partially frame and impose limits on this issue in "Organizational Structures and Internal Party Democracy in Bosnia and Herzegovina" in (ed) G Karasimeonov, Organizational Structures and Internal Party Democracy in South Eastern Europe, Gorex Press, Sofia, (2005), pp 115

37. Article 6 of the Constitution of Croatia of 1990

38. The article 6 of the Croatian Constitution of 1990 was amended in 2000 and the provision on the territorial organization of the parties was dropped, and became part of the Act of Political Parties. 
framework on party financing in all of these countries, despite the many legal changes and improvements, leaves room for abuse, with the silent consent of the main political parties. ${ }^{39}$ There is a need to pass legislation that will further regulate and restrict party finance.

Roughly speaking, all parties in Western Balkans countries have the same organisational model. The characteristics concerning their membership, local organisation, organisational levels, party organs (type and number), selection procedure, and relationship to the parliamentary parties, show substantively more similarities than differences. In this way, they fit the theory that organisational similarities among European parties can be explained by national traditions, promoted by Scarrow, P. Webb and D.M. Farrell ${ }^{40}$, or in the case of the parties in Hungary and Czech Republic, by Biezen ${ }^{41}$ and Deegen-Krause. ${ }^{42}$

We can describe the organisational model through several characteristics: very, very limited or no existent role of non-members in party life; indirect role or limited direct role of party members in decision-making process; a hierarchical internal order; same (copied) organisational patterns on every level; indirect elections of central organs; overlapping between the party in the central office and in the public office; a lack of factions; weak influence of horizontal/functional groups (women, youth, minorities, etc.); absence of affiliated organisations; limited autonomy of the parliamentary party/group; party leaders as holders of the most influential public positions. Shortly, internal party democracy is not a priority in any of the parties. On contrary: their efficient management is.

Organisational uniformity has somehow erased the distinguishing characteristics that have marked some parties in their beginnings in 1990s: Social-democratic parties' communist heritage; Liberal parties' elitism; Popular Parties' conservatism. ${ }^{43}$ It is difficult today to find traces of specifics in party organisational structures.

One additional common feature of the political parties in Croatia, Serbia, Montenegro, Albania and Macedonia is the frequent change of their statutes, at the end of their congresses/conventions. However, these changes do not mean introduction of effectively new organisational structures. I could classify the changes in parties in Western Balkans countries

39. I expressed this view in my paper on "Legal Framework on financing the political parties", presented at the Conference on "Good Practices for financing of Political Parties and Campaign Financing", 30 -31 October 2013, Skopje , organised by OSCE/ODIHR and State Commission for Prevention of Corruption of the Republic of Macedonia

40. H A Scarrow, P Webb and D M Farrell, From Social Integration to Electoral Contestation: The Changing Distribution of Power within Political Parties, in R J Dalton and M P Wattenberg (eds.), Parties without Partisans: Political Change in Advanced Industrial Democracies. Oxford: Oxford University Press

41. Ibid

42. K Deegan-Krause, Elective Affinities: Democracy, Nationalism and Party Competition in Slovakia and the Czeck Republic, Stanford University Press, Palo Alto (2005)

43. More about ideological profile of the political parties: Siljanovska-Davkova G, Political Parties, Values and Democratic Consolidation, Civic and Uncivic Values in Macedonia, (ed) Ramet, S, Listhung. O, and Shimkus, A, Palgrave Macmillan, London, (2013), pp115-131 
as evolutionary (Panebianco) ${ }^{44}$, or through Harmel's5 "life-cycle"approach. The mentioned changes are more intended to regulate some unregulated issues or to adapt rules to new needs of management, than to reform the party in question. Some of the changes were caused by the crisis in party discipline, calls for factions, or disobedience of the leadership. But, the "discrete changes" 46 usually resulted with additional centralisation, instead with decentralisation. In most cases, there were not "system-level" changes ${ }^{47}$ In the case of the parties in Western Balkans, Janda's proposition that electoral defeat is "the mother of party change" can be applied to them only to a point, having in mind that limited number of changes have taken place after electoral victory. ${ }^{48}$

Uniformity, as I previously mentioned is not based on legal reasons but rather derives from the same way of establishment. All of them have "top-down" origin, with a prominent role by party patrons and elites. Lacking democratic tradition and time for democracy exercise, and previously living under similar communist regime, the elites inclined towards similar organisational models, copying one another. Indeed, they did not consider the organisational model as a means to attract voters.

The internal structures of the political parties include at least three or four layers. Regarding the party on the ground, members are organized in local organisations, or branches. The executive bodies make most local decisions, initiate activities and encompass the bulk of party activists. The intermediate level is often a copy of the local one. At the national level there is a striking similarity among different parties and different countries in Western Balkans. The national conventions/congresses discuss different policies, pass party programs, adopt statutes and elect central organs. Comparative view shows that the executive is the main political and operative organ that helps the party leader to manage the party.

A party in a public office in Western Balkans, similarly to the other post-communist democracies ${ }^{49}$, is often indistinguishable from a party in central office. Namely, MPs and ministers are regularly "ex officio" members of one or more central organs of the political parties. But, always and in all of the countries and parties, the parliamentary party is subordinated to the party leadership. The parliamentary parties lack autonomy in creating platforms, in party bargaining, in financial matters. But, there is also reversed influence when MPs are ex officio members of the bodies at local or intermediate level. This situation could be also considered as central office control on the ground.

Internal party democracy means firstly, that the party is established from the "bottom-up" and that there is vertical power sharing among different levels (local-intermediate-central)

44. A Panebianco, Political Parties: Organization and Power, Cambridge University Press, (1988), pp 239250.

45. R Hamel, Party Organizational Change: Competing Explanations?, in: R Luther, and F. Müller-Rommel, (eds.), Political Parties in the New Europe: Political and Analythical Challenges, Oxford University Press, Oxford (2002), pp 119-142

46. Ibid, pp 125-128

47. Ibid, pp 121-125

48. About this writes K. Janda in "Comparative Political Parties: Research and Theory", in A W Finifter (ed.), Political Science: The State of Discipline II. Washington, DC: American Political Science Association.

49. I Biezen, Political Parties in the New Democracies: Party Organization in Southern and East-Central Europe, Palgrave Macmillan, London (2003), pp 214-216 
and that the members of the local branches are able to influence the decision making process (party on the ground); secondly, that there is participatory democracy or inclusion of the members, and different bodies and structures, in the decision making process, as well as constraints the executive organs of the party. If we speak of "big democracy", there are also "many democracies in one" including the party democracy. Indeed, internal party democracy is not one-dimensional, but multi-dimensional concept. For example, internal democracy could be reached by decentralisation but also by direct democracy within the party. Further, the wider autonomy of the parliamentary party could be considered as democratic characteristic, but vice versa, its accountability to the party membership could be seen as non-democratic feature through the prism of internal party democracy.

Twenty five years since the introduction of party pluralism, it still seems that the spirit of democratic centralism - in line with Lenin's premise on the alleged "balance" of "freedom of debate", and strict "unity in action" - persists among Western Balkan's parties. The splits that rift many parties require serious re-thinking and re-examination of their internal organisation and decision-making. But, the same is true of those parties that do not have this problem and take pride in their monolithic constitution, while treating factions and tendencies as a "disease". Political parties in the Western Balkans are facing a crisis. Not only have they failed to solve the most important problems of their members, their supporters and the citizenry as a whole, but they do not even address these issues. Worse, the oligarchic tendencies within internal party life are regularly transferred to the state institutions. Autocratic political leaders and dominance of vote-seeking and office seeking over policy-seeking party logic are major factors behind the deep crisis of representative democracy, reflected in a growing absenteeism. Modern parties do not keep their internal structures open to civil society and to the electorate. The party members are lacking freedom of action and expression. Indeed, a certain party discipline is needed to win elections and implement party programs in government. The balance between these two prerequisites mostly depends on concrete political culture in each of the states.

\section{Internal life of Political Parties in the Republic of Macedonia}

\subsection{Legal Framework}

Legislation in the Republic of Macedonia treats only on principle level the issues regarding party organisation and internal party democracy. Pursuant to the Law on Political Parties from 2004, "political parties realise their goals through democratic structures and the expression of political will to participate in elections, as well as through other democratic means., ${ }^{50}$ The law also guarantees the freedom and independence of political parties in acting and determining their own internal structures, goals and elections. ${ }^{51}$ It prohibits the forming of military and para-military structures in the internal organization of parties. ${ }^{52}$ Also in line with internal party democracy is the principle of gender equality as pertaining to party functions..$^{53}$

50. Article 2, Paragraph 2 of the Law on Political Parties: Official Gazette No. 76/04; 5/07;8/07; 5/08 and $23 / 13$

51. Article 6, Paragraph 2 of the Law on Political Parties

52. Article 6, Paragraph 3 of the Law on Political Parties

53. Article 4 of the Law on Political Parties 
This provision is in correlation with Article 64, paragraph 5 of the Electoral Code which guarantees at least one place of each three places from the party list for MPs and for the members of the councils of local units to under-represented gender. As a result of including gender quotas in election legislation in 1998, the representation of women in Parliament increased from $7,5 \%$ in 1988 to $32,43 \%$ in 2011 .

Political parties are organised and act in accordance with the territorial principle. ${ }^{54}$ The Law also says that "political parties are founded at an assembly of founders, at which decisions on a foundation, program and statute are enacted, and its organs are established. ${ }^{55}$

\subsection{Party Organisation}

To assess party organisation and decision-making, i.e. the degree of internal party democracy, we will focus on the analysis on the following several key issues:

- Vertical power sharing - the status of the basic party organisation and its relation to central party bodies;

- The role and the status of the individual member in the internal party life;

- The role and the status of the party leader, party leadership and elected public functionaries; the method of recruitment and control mechanisms;

- The network of horizontal structures and their role in internal party life; and

- The relation of the party to its supporters and civil society.

\subsubsection{Local Organisations versus Central Organisation}

Three political parties active in Macedonia are object of our direct interest in this paper: Internal Macedonian Revolutionary Organisation - Democratic Party for Macedonian National Unity (VMRO-DPMNE); Social Democratic Party (SDSM) and Democratic Party for Integration (DUI). Why are these three parties selected? In 25 years democratic transition and consolidation and the two-party system, or better said two-and-a-half party system, the main political game was between VMRO-DPMNE and SDSM, the first one with conservative ideology, and the second with social-democratic ideology. DUI appeared on political scene, after the armed conflict in 2001, deriving from National Liberation Army and from then is the most influential Albanian party, which has ever since its establishment been part of the post-election ruling coalition in the country, with the exception of two years, between 2006 and 2008 when the Democratic Party of Albanians was a coalition partner of VMRO-DPMNE.. All three parties could be classified as mass parties, organized on the territorial principle. Differences among them, naturally, do exist, but uniformity is the main organisational characteristic. Another important feature is hierarchy and subordination between the central and local level.

The centralisation or decentralisation of decision-making is an important dilemma of internal party democracy. The basic question is: do local party organisations have a participatory role in the decision-making process or should they only initiate, propose and comment on decisions, but not to decide themselves?

Formally, or de jure SDSM has a decentralized model of organisation and the VMRO-DPMNE and DUI have a centralized model of organisation.

\footnotetext{
54. Article 7 of the Law on Political Parties 
In this respect, in SDSM, the municipal organisation and its bodies are guaranteed participation in the creation and implementation of party policy, putting forward candidacies for its bodies and the nomination for candidates for MPs and for councillors at the local level. Decisions/rules regarding its foundation and termination are enacted by the Central Board of the SDSM. The bodies of the municipal organisation are: The Conference, The President, The Presidency and The Supervisory board. The bodies of SDSM at state level are: The Congress, The President, The Secretary General; The Central Board and The Supervisory Board. A provision designed to encourage a more proactive role for the municipal organisation allows one-third of them to ask for summoning of an extraordinary Congress. The composition of the Congress reflects the internal party structure (an inclusive model), comprising: The President of the party; The Secretary General; the members of the Central board and the Supervisory board; the presidents of the municipal organisations; the president of the Skopje's board, the president of the Social Democratic Youth, one delegate per certain number of members from the municipal organisations, MPs, ministers and deputy ministers. ${ }^{56}$ The Central Board as the highest body between two congresses deals with appeals lodged against decisions taken by municipal organisation.

Several distinguished members of SDSM, among whom are: a former Prime minister Vlado Buckovski, a former minister of Foreign Affairs, Ilinika Mitreva, a former Minister of Finance and former presidents of the parliament, Nikola Popovski and Ljupco Jordanov, a former Minister of Justice as well as former general secretary of party, Georgi Spasov, and few others, openly and publicly called for statutory changes, that will allow for direct election of the President of SDSM, direct election of candidates for MPs and other candidates for functions, in the name of internal party democratisation. Their voice was not heard. Some of them left the party and established a new one, and some remained in it, as ordinary members, without any party functions.

In VMRO-DPMNE,the central organs are: The Congress, The President, The Central Committee, The Executive Committee, The Statutory Commission, The Audit Committee for Finance and The Convention for the Selection of the Candidate for the President of the Republic of Macedonia. The President of the party and the Executive Committee play powerful roles in constituting party organs at all levels, including the election of functionaries as well as in decision making process. De jure, the municipal party organisation is treated as the basic form of organizing party members and the foundation and competencies of the municipal bodies are regulated by the Rules of Procedure. But, the hierarchy and the subordination in the relation between central and local party organs can be seen in the procedure of appointing and dismissing the presidents of the municipality committees by the executive committee of the party, and by the proposal of the President of the Party.

DUI is a centralized and personalized party with hierarchical relations between central and local bodies. It is organized on a territorial principle, with branch and sub-branch offices, and local councils. The President of DUI establishes the branch offices through the verification of their foundation. The branch office is formed within the territory of a single municipality. The organs of the branch office are: The President, the Management Board, the Presidency and the Secretary. ${ }^{57}$ The party bodies at central level are the following: the

56. Article 46 of the Statute of SDSM of 2013

57. Article 18 of the Statute of DUI of 2009 
Congress, the General Council, the Management Board, the President, the Presidency, the Statutory Committee, the Supervisory Committee and the Court of Honour. ${ }^{58}$ The Congress is the highest body of the party. A regular congress is being summoned every four years. The President can summon an extraordinary Congress if requested by two-thirds of the members of the management board or upon request of half of the presidencies of branch offices that make up more than $50 \%$ of overall membership.

\subsubsection{Member's Participation in Decision-Making}

Formally all three parties guarantee their members a long list of rights as well as inclusion in the decision-making process.

The members of SDSM have the following rights and obligations: to participate in the creation and implementation of party politics and in the undertaking of initiatives that do not contradict the program and the statute; the right to be a candidate for party organs or to be on party lists for parliamentary, presidential and local elections; the right to be informed about party activities and the right to have a critical view of them; the right to have separate opinions, proposals and positions that may place them in the minority during debates and to ask for a review of those proposals when they consider the conditions to be right. ${ }^{59}$ The statute also guarantees the autonomy of the personality of the member and the active role of membership in decision-making process. The membership may be ended on account of: simultaneous membership in another political party in the Republic of Macedonia; if as a member or an MP, mayor, councillor or elected functionary in the executive, does not act in accordance with the program or the statute of the party; if by his/her behaviour he/she tarnishes the reputation of the party. The decision to terminate membership has to be submitted to the member in a written form. The member is entitled to appeal to the Central Board of the SDSM, when the decision has been made by the Presidency. In cases when the Central Board has made the decision, it is the Supervisory Board that will decide on the appeal. ${ }^{60}$ The statute envisages the formation of a Permanent Democratic Forum in order to enable members have insight into and control over the party organs. ${ }^{61}$ The bodies of SDSM can work and enact abiding decisions if a half of the members are present, and the decisions are passed on a majority votes. ${ }^{62}$ If at least $30 \%$ of the total number of members oppose the decision or abstain, the adoption of such decision shall be postponed until the next session.

The statute of SDSM does not contain provisions on prohibition or allowing of factions or tendencies. The leadership has explained on several occasions that there are no factions within the party lines and that the party has a monolithic structure. But, one of the prominent former members of SDSM, Tito Petkovski tried to establish a faction, but was not allowed. He left the party and founded a new party - New Social Democratic Party (NSDP).

58. Article 20 of the Statute of DUI

59. Article 8 of the Statute $\mathrm{SDSM}$

60. Article 9, Paragraphs 5 and 6 of the Statute of SDSM

61. Article 17 of the Statute of SDSM

62. Article 61 of the Statute of SDSM 
The rights, commitments and responsibilities of members of VMRO-DPMNE are: to participate in the work of the party; to elect and to be elected to the party bodies; to forward proposals for more successful work of the party. The member is committed to pay membership fee and to abide by the program, the statute and other party documents. The statute of VMRO-DPM$\mathrm{NE}$ also does not contain provisions on factions and tendencies, but they have been a reality in the party: in 1994, Mr Vladimir Golubovski left the party and formed the VMRO-Democratic party; in 1999, Mr Boris Stojmenov, a former finance minister from VMRO-DPMNE, left the party and founded the VMRO-Macedonian; in 2001, Mr Boris Zmejkovski, one of the founding fathers of VMRO-DPMNE, left the party and formed VMRO-the Real; in 2004, the first president of VMRO-DPMNE, Mr Ljubco Georgievski left the party and formed VMRO- the People's Party, and 12 MPs from the VMRO-DPMNE transferred to the new party. In 2004, the former Vice-President of VMRO-DPMNE, Ms DostaDimovska, after her request for faction was denied, left the party and formed the Democratic Republican Party. In meantime, the VMRO-Democratic Party and VMRO-the Real returned to the old party. In 2012, a part of the VMRO- the People's Party, including its president Mr Marjan Dodovski joined back VMRO-DPMNE. Some of the members of VMRO-People's Party remained with Ljupco Georgievski, who became the President of that party again.

Pursuant to the Statute ${ }^{63}$ "membership in DUI is free and on voluntary basis. The membership process is carried up via the party bodies, closest to the location of the citizen's household. The members are entitled to: participate in the work of party; elect and to be elected in the party bodies; be informed on party activities; forward proposals, suggestions and remarks; be familiarized with the acts of the party organs; defend the honour, dignity and interests of the party. A party member can be excluded for acts contrary to the Program and the Statute, abuse of finances, as well as for any immoral or compromising behaviour." ${ }^{64}$ The member can also be excluded because of passivity or non-payment of membership fee. The excluded member can appeal by submitting an objection before the Presidency, and in the final instance, before the Management Board.

In Macedonian political reality the party membership is not actively included in party life. Its activities are mainly related to the elections. The lack of a democratic tradition, including the internal party democracy conditions, as well as the legacy of the previous communist political system, are reflected in deficiencies inside the parties: lack of tolerance and dialogue; banning of factions; reluctance to consider alternative ideas and critics; lack of courage to speak up for the fear of being dismissed from the party or being considered a "traitor"; lack of transparent decision-making process. So, in my opinion in these 25 years the parties decision-making has been more decision-imposing than a consensus seeking process. Ideology and policy programs have become less salient features of internal party life, which has led to a gradual decline in the numbers of ideologically committed members and an increase of "pragmatic" members. Personal material interests and benefits prevail over values, beliefs and political convictions.

\subsubsection{The Party Leader}

"Presidentialism" is a well-developed concept in all Macedonian parties. The political parties are identified by their presidents ("chairman+seal"). Nevertheless, there are two groups of

63. Article 6 of the Statute of DUI of 2009

64. Article 11of the Statute of DUI of 2009

Revista Ballot - Rio de Janeiro, V. 2 N. 1, Janeiro/Abril 2016, pp. 01-26 
parties: those where presidential power has been statutory supported (VMRO-DPMNE and DUI), and those where presidents have been de facto, acting in accordance with the "winner takes all" principle (SDSM).

The President of the SDSM represents the party; he/she leads the party in between the sessions of its bodies; he/she participates in the creation of party policy; summons the sessions of the Central Board and the Presidency and chairs them; nominates the Vice-President of the party, and appoints and dismisses presidents of the municipal organisations and the president of the party organisation of Skopje, in accordance with the procedure as determined by the Central Board. ${ }^{65}$ The Vice-President: participates in policy creating; creates the international party's strategy and maintains the contacts with international representatives; replaces the president when needed, upon his/her authorisation. ${ }^{66}$ The mandate of the President and Vice-President is four years, with the right to re-election. De iure, the President of SDSM is "primus inter pares", but in practice, he is the key subject in the recruitment of the party leadership, not only on central level but also on the local one. He also plays a key role in putting forward candidacies in the election of public functionaries from the SDSM at all levels, and the creating and implementing party politics. SDSM lost parliamentary elections in 1998, but the membership and party bodies did not ask for a resignation from the president. Nor did he offer to resign. When SDSM lost the parliamentary elections in 2006, the Congress voted non-confidence to the President Mr Vlado Buckovski. In 2008 SDSM again lost the elections and the President of the party, Ms Radmila Shekerinska resigned. The SDSM was defeated in 2011 parliamentary elections, but neither the membership, nor the president $\mathrm{Mr}$. Branko Crvenkovski mentioned resignation. Nevertheless, at the Congress in 2013 the delegates elected the new President and Vice- President of the party and adopted the new Statute.

The President of VMRO-DPMNE is both "de iure" and "de facto" the key party figure. $\mathrm{He} / \mathrm{she}$ can be (re)elected by absolute majority of the delegates (secret voting), upon proposal of at least 30 delegates at the Congress. ${ }^{67} \mathrm{He}$ is the president of the central committee and also the president of the executive committee. The president has wide competencies: he/ she represents the party; chairs the sessions of the central, executive committee and annual assembly; defines decisions on behalf of the party; actively participates in the party policy creation; is in charge of the implementation of the statute, the program and other party acts; concludes agreements and sign acts; proposes the election and dismissal of vice presidents, the secretary general and the members of executive committee; proposes the election and dismissal of the statutory and supervisory commission between two congresses; determines the timing of annual assembly ${ }^{68}$

The Executive Committee of VMRO-DPMNE, as a political-executive body, acts upon the political directions, conclusions and tasks, given by the president and the central committee, reporting the both of its work.

The Union of Young Forces of VMRO-DPMNE reports not only to the Central Committee and Executive Committee, but also to the president.

65. Article 31, point 6 of the Statute of SDSM from 2013

66. Article 31-a of the Statute of SDSM from 2013

67. Article 20 of the Statute of VMRO-DPMNE from 2004

68. Article 22 of the Statute of VMRO-DPMNE from 2004 
The President of DUI is elected with absolute majority by the congress with secret vote. $\mathrm{He} / \mathrm{she}$; represents the party; has a mandate of four years and he/she can be re-elected. He/ she is authorized to nominate candidates for the members of: the General Council, vice-presidents of the party; General Secretary; as well as holders of other party functions; establishes inner presidency as own advisory body; can establish different working bodies. He has to inform the Congress on his/her work. ${ }^{69}$ On behalf of party he/she can annul the decisions of the party branches if is not in conformity with the program and statute, and can abolish a branch office or sub-branch office. ${ }^{70}$ The President of DUI is at the same time the president of the general council, as the highest organ between two congresses. He actively influences the realisation and valorisation of the party program, the statute and other party acts.

The immense power of DUI can be best seen in the statement of the former minister $\mathrm{Mr}$ Agron Buxhaku, who said: "I am not accountable to the Prime Minister, but to my party leader". During the local or parliamentary elections, next to the billboards of DUI candidates for mayors, or MPs there were posted as well billboards with the President Mr Ali Ahmeti. He was and is an elected MP, who is one of the most absent deputies from the parliamentary sessions.

Macedonia has lacked leaders with vision, who have been willing to make sacrifices for the country and its citizens. For twenty five years we have seen many irresponsible leaders inexperienced in the procedures of democratic life. Some of them have not had any sort of notable academic or professional background and have lacked references from their previous professional engagements, as well as, in certain instances also integrity and values. They have been perceived as self-interested and arrogant. They were often surrounded by "business-politicians", who have built their careers through clientelism(the use of state resources for in the interest of those in power). So, businessmen, instead of running their business, run the country, (ab)using their political status for own interests. We failed to create a political system based on stable institutions. Instead, it relies on party leaders, who behave like political gods. Macedonian party leaders have been synonymous with an authoritarian mentality in the political leadership. They put themselves above the party, party organs and party members, thus becoming serious obstacle to the democracy and progress of their parties and the country as a whole. We need more idealistic, intelligent, well-educated, honest and patriotic leaders with integrity, strong willingness and a high sense of commitment and responsibility. We need visionary leaders, reformers who can bring energy to transforming the country along western democratic lines. We need post-modern politicians, able to push modernisation and democratisation programs, who will take courageous and decisive action toward establishing a "one member, one vote" model, with decentralized decision making, autonomous local organisation, respect for and protection of personal opinions - i.e. internal party democracy.

\subsubsection{Selection and Control of Party Leadership and Office Holders}

In all Macedonian parties the president's mandate is four years and there is no limit for re-election. The members of executive board can also be re-elected after four years term. Primaries are unknown category and party leadership is reluctant to stage them, "led by fear of entropy and anarchy". To harmonize the need for efficient leadership with the need for representation of the main party structures, almost all executive bodies are elected by the

69. Article 60 of the Statute of DUI from 2009

70. Article 60, point 5 of the Statute of DUI from 2009 
congress (VMRO-DPMNE, SDSM and DUI). They can be proposed by different actors: municipal organisations, presidents, central bodies, certain number of delegates etc. Knowing that MPs, ministers and deputy ministers are ex officio members of the highest organs on a national or local level, the decision-making process is under the strong control of the president and party leadership. That leads towards development of an elitist type of internal party democracy, while reducing its pluralistic and participatory nature. Since they are selected through a centralized procedure, MPs and councillors are subordinated to and dependant on the party leadership. Despite the fact that parties are financed by the state budget, in accordance with the number of parliamentary seats, money goes directly to the party centre. Parliamentary parties are closer to party leadership than to citizens. So,"homo partitus" is not always "homo democraticus".

The selection/election process of party leadership and office holders is bottom-up oriented. Municipal organisations propose candidates and their election is carried out by the highest party body (congress, convention, or assembly). The procedure, way and criteria for putting forward candidacies and electing party functionaries is determined by the central board (SDSM, DUI) or central committee (VMRO-DPMNE) as the highest bodies of those parties between two congresses.

The election of SDSM functionariesis carried out via secret balloting, in two rounds. In the first round, a majority of the votes of attendees is required, under the condition that it represents no less than one-third of the total number of the members of the body. Two best candidates proceed to the second round. Relative majority, but not less than one- third from the total number of members is sufficient for victory. At least $40 \%$ of all SDSM body members must represent either gender and at least $30 \%$ must be younger than 32 years. ${ }^{71}$ The calling of a congress, in a form of convention is mandatory prior to parliamentary and presidential elections in order to nominate candidates, as well after elections, in order to analyse results and express the (non)confidence in bodies.

The Congress of VMRO-DPMNE as its highest body elects the President of the party, on the proposal of at least 30 delegates. The election is in two rounds. The first round requires the absolute majority of votes, and the two best ranked candidates go into the second round, in which whoever obtains the relative majority wins. The Central Committee of VMRO-DPMNE, as the highest body between two congresses, nominates the candidates for MP.

In DUI, the General Council nominates the office holders (ministers, deputy ministers and other functionaries) based upon the proposals of the president, as well as the list of MPs, which has to be verified by the General Council as the highest body between two congresses. ${ }^{72}$

The statutes of SDSM, VMRO-DPMNE and DUI contain provisions that regulate the relations between MP groups and party. In all three parties, parliamentary groups have to work in accordance with the program and statute of the party, they have to consult with party bodies and to submit reports on their work to party organs. There is a similar relationship between councillor groups and mayors, on one side, and the party, on the other.

Functionaries enjoy special status in each political party. By function, the MPs, ministers and deputy ministers are members of the congress. By function, they are also members of the conference of municipal organisation and its presidency, but are not entitled to vote.

71. Article 70 of the Statute of VMRO-DPMNE from 2004

72. Article 62, point 5 of the Statute of DUI from 2009 
De facto, the process of selection/election of party officials is degenerating into a game between the "candidates" and the leader and leadership, instead of fair and open competition. The leadership selects/elects obedient party friends/servants rather than persons with integrity, who can properly represent the electorate. The proportional electoral model with fixed electoral lists favours the leadership and enables the strong influence during the selection/election process by a limited group. All parties have "cadre commissions" that evaluate and nominate party function holders, but actually it is the president and an informal inner cabinet, led by the servility of candidates for office and their business connections, who have the last word. Therefore, Macedonia functions like "party state", not as a "Rechstaat". The high public officials selected by "spoils system" work as " party officials", not as state officials, who should work for the benefit of citizens. "Partitocrazia" penetrates all areas of the state and the ruling parties colonize society and state. ${ }^{73}$ Clientelism has grown rapidly. Politicians control access to the principle sources of wealth, the awarding of public contracts, the granting or withholding of licenses to the certain types of businesses. Clientelistic distribution of resources is a significant means of voter mobilisation. Another aspect is the provision of employment and appointment of party workers to public institutions. This is a well-known phenomenon: "lottizacione" is the system through which the major political parties parcel posts in public bodies and companies. Partitocrazia and clientelism are the bases for corruption and facilitate its spread. ${ }^{74}$

\subsubsection{Horizontal Structures and their Relationship to Sympathizers and Supporters}

There are different horizontal structures in all Macedonian parties, but they serve more as a decorative rather than functional purpose. De iure parties have similar horizontal structures. In accordance with the Statute, Social Democratic Youth of Macedonia (SDMM) is part of SDSM horizontal network, including both party members and supporters (Artical 72 and Artical 73). SDMM is present at all levels of SDSM and is entitled to 30\% representation within all bodies. Its president is by function member of the congress. The women in SDSM have active role and they fought to gain $40 \%$ representation in all party organs.

The Statute of VMRO-DPMNE envisages the following working groups: The Union of Young Forces, the Union of Women, the Union of Veterans, several forums and the Academy of Politics. Their organisation and work are regulated with specific rules of procedure. ${ }^{75}$ These groups are represented in the highest bodies of the party.

Women from SDSM, VMRO-DPMNE, and DUI actively lobbied for the introduction of a $30 \%$ gender quota in electoral legislature. They have also supported the foundation of Club of Women MPs in 2003, as an informal parliamentary body.

The Statute of DUI envisages the formation of a forum of young people and a forum of women on the decision of General Council, which also adopts the acts on procedure, organisation and work of these forums.

73. More about this: G Siljanovska-Davkova, The Particularity of Democratic Transition of the New States in the Western Balkans: the Case of Former Yugoslav Republics, in Key Developments in Constitutionalism and Constitutional Law (eds) L r. Basta Fleiner, \& T Marinkovic, ELEVEN International Publishing, Hague, pp 77-79

74. J Newell, Parties and Democracy in Italy, chp.1, 3,9, Ashagate, Aldershot (2000) pp 45

75. Article 41-44 of the Statute of VMRO - DPMNE from 2004 
The intent to attract scientific and expert potential has led the parties to the establishment of different kinds of think-tanks. SDSM has its Council of Intellectuals, which is composed of renowned personalities, who do not have to be party members. VMRO-DPMNE has a Council of Intellectuals as well as an Academy for Politics, which provides continuing political education to the membership.

All the parties are open for cooperation with supporters and individuals who have no party affiliation. For this purpose, they can "participate in the work of the party bodies, with no right to decision-making". The Central Board of SDSM or the Central Committee of VMRO-DPMNE can form different commissions on: political system, education, culture, ecology etc.

Parties also organize open meetings of party officials, office holders and sympathisers and supporters. Internet and new media has become more and more important tool for communication between parties and sympathizers.

But, de facto there is no adequate horizontal power sharing within Macedonian parties,i.e different internal groups and specific interests are not properly included in decision-making. Political parties also lack permanent cooperation with their supporters. Usually, before elections, they develop ad hoc activities for sympathizers in search for votes. Most of intellectuals are unwilling to join party think-tanks since they fear they could lose their intellectual independence and integrity. Thus, these bodies have not developed into powerful policy-creating tools. Parties have not allowed significant influence from different internal groups: women, youth, knowledge elite, and have not paid enough attention to those from another ethnicity, religion or different sexual orientation. Thus, party politics rarely includes negotiations, compromises and bargaining among different actors, in what Lindblom has called "partisan mutual adjustment", which includes "consensus seeking"and provides for horizontal power sharing. ${ }^{76}$ There is not one "best way" of policy making. Some issues require highly political, pluralistic bargaining and an incremental approach, while others need a more planned and analytical approach. The lack of inclusion of relevant party interests, streams and groups as well as communications with supporters and civil society, results in policy making that is to a great extent a political process, not a technocratic one, and a partisan rather than an administrative one. It is a process in which the party leaderships have had exclusive rights to create policy, opening the door to potential conflicts among the different actors.

Policy-making on the road toward EU membership/integration requires increased independence from direct political control. ${ }^{77}$ Indeed, we have witnessed that some policies are in essence efforts to force changes compatible with ideological goals. But in Macedonia, the personal self-interests of the main political actors play the most important role in policy making: that is what makes it elitist. The party elites make all the key decisions and often it is the business elite who become the most influential political actor.

76. C Lindblom, "The science of muddling through", Public Administration Review, Vol.29 (2),(1959).

77. V Della Sala, Hollowing and Hardening the State: European Integration and the Italian Economy, in : M Rhodes, \& M Bull, (eds), Crisis and Transition in Italian Politics, Frank Cass, pp 19-25. 


\section{Conclusions}

The political parties in Western Balkans, including the parties in Republic of Macedonia are like the Roman god Janus, who had two faces: one that is statutory-democratic and another that is realistic-authoritarian and oligarchic. The situation within the parties, including those analysed above, is not identical on normative-realistic level, but there are some general tendencies shared by all, including the following:

- The authoritarian, presidential and oligarchic elements dominate poliarchic ones;

- Centralised decision-making supresses decentralised action;

- The recruitment of public and administrative functionaries is in the hands of the highest political leadership or under its strong influence;

- The membership is in principle inactive, disciplined or follows a routine pattern;

- The responsibility of the party leadership and public functionaries is relativized and suspended, even following the loss of parliamentary or local elections. ${ }^{78}$

- In the absence of precise criteria and procedures, a patronage model of putting the candidacies by those in power is what actually works in practice;

- The submissive political culture becomes a modus vivendi because critical opinion and behaviour is sanctioned with exclusion, while obedience is rewarded;

- In the name of electoral victory, hate speech is tolerated;

- On behalf of monolithic structure and unity the statutes that guarantee different or separate opinions are broken, and the same with the constitutional provision for the right of MP to vote according to his/her own beliefs; ${ }^{79}$

- Through the appointment of selective staff to party headquarter positions, the right of local party organisations to elect their own leadership is being suspended;

- The internal bodies that represent women, youth and other relevant groups still do not have strong institutional shot at promoting and protecting their legitimate interests;

- The factions and tendencies are not guaranteed in almost almost all party statues, but even when they are (New Social Democratic Party - NSDP), they are decorative element.

\section{What changes are needed for internal party democracy?}

- Power sharing between the central level and local levels;

- Opening the question on tendencies and factions and regulation of these;

- Direct election of the leader, leadership and office holders by the principle: one-member-one vote;

- Wider inclusion of members and horizontal structures in decision-making;

- Stronger de-accumulation of functions and limited mandates of party functionaries.

- Transparency and control over the work of local, state and public functionaries;

78. There are exceptions, indeed: The President of the Liberal Democratic Party (LDP), Jovan Manasievski resigned after catastrophic results at the 2011 parliamentary elections in which LDP didn't get any parliamentary seat.

79, Art. 62, Paragraph 3. of the Constitution of the Republic of Macedonia 
- More autonomy for parliamentary groups;

- More appropriate representation of underrepresented groups in party organs:

- Activation of think-tanks in strategy-creation and policy-making;

- Reinforcement of the inclusive model of internal party democracy through wider participation of membership and supporters;

- Continuous education of membership on policy-making and good governance;

+ Building of a civic political culture;

- Creation of party architecture and decision-making processes compatible with the parties in EU member-states;

+ Building partnership with civil society;

- Promotion of a philosophy of dialogue, tolerance and cohabitation;

- Strengthening of readiness for consensus over issues of national significance;

- Developing wider and stronger cooperation with related European parties;

- Party reforms towards building model of proactive and not reactive political discourse, capable of mobilising, educating and inspiring citizens, and not only responding to their request.

\section{References:}

\section{Books:}

Almond, G A and Verba, S, The Civic Culture: Attitudes and Democracy in Five Nations, Princeton Press, Princeton, (1963).

Almond, G A, and Verba, S, (eds), The Civic Culture Reviseted, Little, Brown, Boston, (1980). Beck, P A, Party Politics in America, Longman, 8 th edn, New York, (1996)

Biezen, I, Political Parties in the New Democracies: Party Organization in Southern and EastCentral Europe, Palgrave Macmillan, London, (2003).

Budge, J and Farlie, D, Explaining and Predicting Elections: Issue Effects and Party Strategies in Twenty-Three Democracies, Allen\& Unwin, London, (1983).

Crew J, and Denver D, (eds.), Electoral Change in Western Democracies: A Framework for Analysis, St Martin's Press, New York (1985).

Della Sala, V, Hollowing and Hardening the State: European Integration and the Italian Econo$m y$, in : Rhodes, M\& Bull, M (eds), Crisis and Transition in Italian Politics, Frank Cass (1997) Goati, V, Political Parties and Parties' Systems, FPN, Podgorica, 2008;

Čular, G, Organizational Development of Parties and Internal Party Democracy in Croatia in : G. Karasimeonov (ed) Organizational Structures and Internal Party Democracy in South-East Europe, Gorex Press, Sofia, (2005)

Dalton, RJ, Flanagan, S, and Beck, P, (eds.), Electoral Change in Advanced Industrial Democracies, Princeton University Press, Princeton, (1984) 
Dalton, RJ, Citizen Politics: Public Opinion and Political Parties in Advanced Western Democracies, Chatman House, $2^{\text {nd }} e d n,(1996)$

Deegan-Krause, K, Elective Affinities: Democracy, Nationalism and Party Competition in Slovakia and the Czeck Republic, Stanford University Press, Palo Alto (2005).

Duverger, M, Political Parties: Their Organization and Activity in the Modern State, Methuen, London (1954)

Eldersveld, S J, Political Parties: A Behavioral Analysis, Rand McNally, Chicago (1964)

Epstein, LD, Political Parties in Western Democracies, Praeger, New York (1967)

Farrel D, and Webb P, Political Parties as Campaign Organizations in R. Dalton and M Wattenberg (eds) Parties without Partisans: Political Change in Advanced Industrial Democracies, Oxford University Press, Oxford (2000)

Flanagan, W, and Fogelman, E, Functional Analysis, in J.C. Charlesworth (ed.), Contemporary Political Analysis, Free Press, New York, (1967).

Hamel, R, Party Organizational Change: Competing Explanations?, in: K.R Luther,/F.MüllerRommel (eds.), Political Parties in the New Europe: Political and Analythical Challenges, Oxford University Press, Oxford (2002).

Katz, R S, and Mair, P, The Ascendency of the Party in Public Office: Party Organizational Change in Twentieth-Century Democracies, in: J.R. Montero, J J Linz (eds) Political Parties: Old Concepts and New Challenges, Oxford University Press, Oxford, (2002)

Katz, RS, and Mair. P (eds), How Parties Organize. Change and Adaptation in Party Organizations in Western Democracies, Sage, London (1994)

Katz, RS, and Mair, P, Party Organizations: A Data Handbook on Party Organizations in Western Democracies, 1960-1990, Sege, London, (1992a)

Katz. R S, and Mair, P, (eds), How Parties Organize. Change and Adaptation in Party Organizations in Western Democracies, Sage, London (1994)

Katz, R S, and Mair, P, Introduction: The Cross-National Study of Party Organizations : A Data Handbook on Party Organizations in Western Democracies, 1960-1990, Sege, London, (1992b)

Kircheimer, O, The Transformation of Western European Party Systems in J. La Palombara and M. Weiner (eds.), Political Parties and Political Development, Princeton University Press, Princeton, (1966). 
Lawson, K, Political Parties and Linkage: A Comparative Perspective, Yale University Press, London, (1980)

Lijphart, A, Patterns of Democracy: Government Forms and Performance in Thirty- six Countries. Yale University Press. New Haven, Conn, (1999).

Lipset, S M, and S. Rokkan, S, (eds), Systems and Voter Alignments, Free Press, New York: (1967a)

Michels, R, Political Parties, Free Press, New York (1962)

Moravcsik, A, The Choice for Europe: Social purpuse and state power from Messina to Maastricht, UCL Press, London (1999)

Newell, J, Parties and Democracy in Italy, chp.1, 3, 9. Ashgate, Aldershot (2000)

Ostrogorski, M, Democracy and Organization of Political Parties, Macmillan, London (1964[1902]

Panebianco, A, Political Parties: Organization and Power, Cambridge University Press, Cambridge, (1988)

Rae, D W, The Political Consequences of Electoral Laws, Yale University Press, $2^{\text {nd }}$. edn. New Haven.Conn (1971).

Robertson, D (1976), A Theory of Party Competition. John Wiley \& Sons. London (1976)

Sartori, G, Parties and Partry Systems: A Framework for Analysis, Cambridge University Press. Cambridge, (1976).

Scarrow, S E, Webb, P, and Farrell, D M, From Social Integration to Electoral Contestation: The Changing Distribution of Power within Political Parties, in R J, Dalton and M P. Wattenberg (eds.), Parties without Partisans: Political Change in Advanced Industrial Democracies. Oxford University Press. Oxford, (2000).

Siljanovska-Davkova, G, Political Parties, Values and Democratic Consolidation, in Ramet, S, Listhung O, and Shimkus A (eds), Civic and Uncivic Values in Macedonia, Palgrave Macmillan, London, (2013)

Siljanovska- Davkova, G, Legal Framework on financing the political parties”, International Conference "Good Practices for financing of Political Parties and Campaign Financing”, 30 -31 October 2013, Skopje , organised by OSCE/ODIHR and State Commission for Prevention of Corruption of the Republic of Macedonia 
Siljanovska-Davkova, G, The Particularity of Democratic Transition of the New States in the Western Balkans: the Case of Former Yugoslav Republics, in Key Developments in Constitutionalism and Constitutional Law (eds) Basta Fleiner, L \& Marinkovic, T, ELEVEN International Publishing, Hague (2014)

Tsebelis, G, Veto Players, Princeton University Press, Princeton (2002)

Vuletič, D, Organizational Structures and Internal Party Democracy in Bosnia and Hercegovina in (ed) G. Karasimenov, Organizational Strucures and Internal Party Democracy in South Eastern Europe, Gorex Press, Sofia, (2005)

Wright,WE, Comparative Party Models:Rational-Efficient and Party Democracy, in: Wright, W E, (ed), Comparative Study of Party Organization, Charles E. Merril Publishing Company, Columbus, (1971)

\section{Articles:}

Alibali, A, Balkani Prerëndimorapo Europa Adriatike, Korrieri, Tirana, 21 August (2003)

Ash, TG, EU Enlargement: Unfinished Symphony, SEESP Newsletter No. 2, July (2004) Glenny, M, and Knaus, G, Thessalonica and Beyond: Europe's Challenge in the Western Balkans, in European Stability Initiative, (2003)

Katz,RS, and Mair,P, The Evolution of Party Organization in Europe: The Three Faces of Party Organization, in W. Crotty (ed.), Political Parties in Changing Age, special issue of American Review of Politics, 14, (1993)

Katz,RS,Mair,P,Changing Models of Party Organization and Party Democracy: the Emergence of the Cartel Party, Party Politics, 1 (1995).

Lindblom, C, "The science of muddling through", Public Administration Review, Vol.29 (2),(1959).

Mudde,C, The Paradox of the Anti-Party Party: Insights from the Extreme Right Party Politics, 2. (1996).

Müller,WC, The Relevance of the State for Party System Change, Journal of Theoretical Politics, 5 (1993)

Young, L / Cross, W, The Rise of Plebiscitary Democracy in Canadian Political Parties, Party Politics (8) 6, (2002) 


\section{Others:}

Constitution of the Republic of Macedonia https://www.google.com/ webhp? sourceid $=$ chrome-instant $\&$ ion $=1 \&$ espv $=2 \& \mathrm{ie}=\mathrm{UTF}-8 \# \mathrm{q}=$ constitution $\% 20 \mathrm{of} \% 20$ the $\% 20$ republic\%20of\%20macedonia

Law on Political Parties: Official Gazette No. 76/04; 5/07;8/07; 5/08 and 23/13

Statute of SDSM of 2013 http://www.sdsm.org.mk/upload/documents/Statut\%20 SDSM\%20nov-2.pdf

Statute of VMRO-DPMNE - http://vmro-dpmne.org.mk/?page_id=174

Statute of DUI of 2009 http://www.bdi.mk/ 
Recebido em: $11 / 01 / 2016$

Aceito em: 23/03/2016

\section{Como citar}

SILJANOVSKA-DAVKOVA, Gordana . Two faces of internal life of political parties in Western Balkans. Ballot. Rio de Janeiro: UERJ. Volume 2 Número 1 Janeiro/Abril 2016. pp. 01-26. Disponível em: [http://www.e-publicacoes.uerj.br/index.php/ballot]

\section{(c) (1) (2)}

A Revista Ballot está licenciada sob uma licença Creative Commons Atribuição - Não Comercial - Compartilha Igual 3.0 Não Adaptada. 